\title{
Author Correction: Fast and multiplexed superresolution imaging with DNA-PAINT-ERS
}

Fehmi Civitci, Julia Shangguan (1), Ting Zheng, Kai Tao, Matthew Rames, John Kenison, Ying Zhang, Lei Wu, Carey Phelps, Sadik Esener (1) \& Xiaolin Nan (1)

Correction to: Nature Communications https://doi.org/10.1038/s41467-020-18181-6, published online 28 August 2020.

In the original version of this Article, the DOI for Reference 21, describing protocols for sample preparation and imaging procedures used in this Article, is incorrectly cited as https://doi.org/10.1038/protex.2011.204. The DOI link should be https://doi.org/10.21203/ rs.3.pex-1069/v1. This has been corrected in both the PDF and HTML versions of the Article.

Published online: 21 September 2020

(i) Open Access This article is licensed under a Creative Commons Attribution 4.0 International License, which permits use, sharing, adaptation, distribution and reproduction in any medium or format, as long as you give appropriate credit to the original author(s) and the source, provide a link to the Creative Commons license, and indicate if changes were made. The images or other third party material in this article are included in the article's Creative Commons license, unless indicated otherwise in a credit line to the material. If material is not included in the article's Creative Commons license and your intended use is not permitted by statutory regulation or exceeds the permitted use, you will need to obtain permission directly from the copyright holder. To view a copy of this license, visit http://creativecommons.org/licenses/by/4.0/.

(C) The Author(s) 2020 